\title{
ISOLASI DAN KARAKTERISTIK BAKTERI LIGNOLITIK DARI LIMBAH PEWARNA TENUN IKAT
}

\author{
Yulita I. Mamulak \\ Universitas Katolik Widya Mandira Kupang \\ yulitairyani@yahoo.co.id
}

\begin{abstract}
ABSTRAK
Limbah pewarna yang dihasilkan oleh industry tenun ikat berpotensi mencemari lingkungan dan mengandung berbagai jenis mikrobia yang berkemampuan untuk mendegradasi pewarna. Penelitian ini bertujuan untuk memperoleh isolat bakteri yang mampu mendegradasi limbah pewarna industri tenun ikat. Isolasi bakteri dilakukan dengan teknik enrichment culture (pengkayaan) pada media MSM (Mineral Salt Medium). Hasil isolasi dari 4 sampel limbah diperoleh 35 isolat bakteri, seleksi kualitatif menghasilkan 12 isolat unggul yang berkemampuan lignolitik dengan daya lignolitik berkisar antara 7,7519,75. Dari seleksi kuantitatif berdasarkan kemampuan dekolorisasi pewarna dihasilkan 3 isolat unggul yaitu isolat bakteri IN1, IN7 dan C5. Identifikasi awal menunjukkan bahwa ketiga isolat memiliki kedekatan dengan genus Enterobacter dan Brucella.
\end{abstract}

Kata kunci: Bakteri, dekolorisasi dan limbah pewarna

\section{PENDAHULUAN}

Tenun ikat merupakan salah satu karya seni lokal yang dilestarikan oleh pemerintah Provinsi Nusa Tenggara Timur (Setiawan, dkk, 2014). Permintaan tenun ikat terus meningkat beberapa waktu terakhir, hal ini menyebabkan permintaan konsumen akan corak dan tren warna kain tenun ikat makin bervariatif, sehingga mendorong penggunaan pewarna sintetis dalam proses pembuatan tenun ikat. Limbah yang dihasilkan pada proses pewarnaan berpotensi mencemari lingkungan. Komponen umum limbah industri tenun ikat adalah zat pewarna, surfaktan, serat dan logam penyusun zat pewarna (Pandey et al., 2007)
Zat pewarna merupakan senyawa organik gabungan antara gugus khromofor pembawa warna dan gugus auksokhrom yang merupakan pengikat antara khromofor dan serat inert (Rahmacandran et al., 2010).

Biodegradasi pewarna mengakibatkan terjadinya perubahan struktur kimiawi pada gugus khromofor atau auksokhrom, atau pada kedua gugus tersebut (Martani et al., 2011).

Biodegradasi merupakan mekanisme pengolahan limbah, dengan memanfaatkan aktivitas mikrobia untuk mendegradasi senyawa toksik yang ada dalam limbah menjadi senyawa yang nontoksik. Berbagai jenis pewarna dapat 
didegradasi oleh beberapa spesies mikrobia baik bakteri maupun jamur, karena mampu memproduksi enzim lignolitik ekstraseluler. Hal ini disebabkan oleh kemiripan struktur kimia enzim yang dihasilkan dengan limbah zat pewarna (Martani et al., 2003). Dalam penelitian ini, kemampuan dekolorisasi terhadap pewarna kain tenun ikat digunakan sebagai parameter untuk menyeleksi keunggulan isolat bakteri yang diperoleh.

\section{METODE PENELITIAN \\ Bahan dan Materi Pokok \\ Penelitian:}

Sumber Isolat, sumber isolat yang digunakan adalah limbah cair dan tanah di sekitar tempat pembuangan limbah industri tenun ikat di Kota Kupang.

Zat Pewarna Sintetik, NaftolASBO-Blue $B$

Media, Mineral Salt Medium (MSM), Nutrient Broth (NB) dan Nutrient Agar.

Pelaksanaan dan Metode Penelitian

Pengambilan Sampel Sebagai Sumber Isolat, limbah pewarna dan tanah di sekitar pembuangan limbah pewarna industri tenun ikat dari daerah Kupang.

\section{Isolasi dan Purifikasi Bakteri}

Isolasi bakteri dilakukan dengan teknik enrichment culture (pengkayaan) (Khehra et al., 2005) dengan cara sebagai berikut:
Lima gram sampel dimasukkan ke dalam $45 \mathrm{ml}$ medium MSM $\left(\mathrm{K}_{2} \mathrm{HPO}_{4} \quad 2,75 \mathrm{~g}, \quad \mathrm{KH}_{2} \mathrm{PO}_{4} \quad 2,25 \mathrm{~g}\right.$, $\left(\mathrm{NH}_{4}\right)_{2} \mathrm{SO}_{4} 1 \mathrm{~g}, \mathrm{MgCl}_{2} \cdot 6 \mathrm{H}_{2} \mathrm{O} \quad 0,2 \mathrm{~g}$, $\mathrm{NaCl} 0,1 \mathrm{~g}, \mathrm{FeCl}_{2} \cdot 6 \mathrm{H}_{2} \mathrm{O} 0,2 \mathrm{~g}, \mathrm{CaCl}_{2}$ 0,002g, Glukosa 5g, Aquadest 1L) yang mengandung zat warna NaftolASBO-Blue $B \quad 500$ ppm, lalu diinkubasi secara aerobik menggunakan rotary shaker dengan kecepatan $150 \mathrm{rpm}$ pada suhu $37^{\circ} \mathrm{C}$ selama 1 minggu. Pada akhir masa inkubasi di buat seri pengenceran tertentu. Isolasi bakteri dilakukan dengan metode pour plate untuk mendapatkan koloni tunggal. Koloni tunggal yang tumbuh, diisolasi kembali pada media yang sama untuk memperoleh kultur murni dan dipelihara dalam media nutrient agar (NA) modifikasi yang ditambahkan zat warna 50 ppm untuk mempertahankan kemampuan adaptasinya terhadap pewarna.

\section{Seleksi Isolat Bakteri}

Seleksi Aktivitas Lignolitik Isolat Bakteri

Seleksi aktivitas dengan menggunakan metode (Rao,1982), dengan metode inokulasi titik pada medium NA yang mengandung asam tanat $1 \%$.

\section{Seleksi Aktivitas Dekolorisasi Isolat Bakteri}

Uji dekolorisasi dilakukan dalam dalam media NB 0,4\% yang ditambahkan pewarna Naftol-ASBO Blue $B \quad 500 \mathrm{ppm}$. selanjutnya diinkubasi dalam rotary shaker 150 rpm pada suhu $37^{\circ} \mathrm{C}$ selama 24 jam. 
Konsentrasi pewarna diukur secara periodik dengan menggunakan spektrofotometer pada panjang gelombang 325 .

\section{Identifikasi Isolat Terpilih}

Identifikasi isolat terpilih hingga aras genus berdasarkan pengamatan terhadap sifat morfologis, fisiologis dan biokimia, selanjutnya membandingkan hasil karakterisasi dengan Bergeys's Manual of Determinative Bacteria $9^{\text {th }}$.

\section{HASIL DAN PEMBAHASAN Isolasi Bakteri dari Lingkungan}

Bakteri lignolitik merupakan bakteri yang mampu mendegradasi limbah pewarna. Menurut Martani et al (2003) bahwa bakteri tersebut dapat mendegradasi pewarna karena ada kemiripan sebagian struktur kimia lignin dengan zat pewarna sehingga bisa cocok dengan sisi aktif enzim lignolitik yang dihasilkan oleh bakteri. Enzim lignolitik ekstraseluler ini dapat merombak senyawa aromatik, polimer sintetik, dan zat warna melalui reaksi reduksi-oksidasi, yang pada akhirnya akan mengoksidasi secara sempurna senyawa - senyawa karbon menjadi $\mathrm{CO}_{2}$ dan $\mathrm{H}_{2} \mathrm{O}$ (Siswanto et al., 2007).

Berdasarkan hasil isolasi sebanyak 35 isolat berhasil diisolasi dari 4 sampel yang diambil. Ke 35 isolat bakteri, dipelihara dan ditumbuhkan dalam medium agar. Seleksi awal ke 35 isolat tersebut didasarkan pada aktivitas lignolitik secara semikuantitatif menggunakan inokulasi titik diatas medium NA modifikasi ditambah dengan asam tanat. Dengan tolak ukur warna coklat dan perbandingan diameter zona coklat dengan diameter koloni bakteri, ditentukan isolat unggul yang akan digunakan dalam penelitian tahap selanjutnya.

\section{Seleksi Aktivitas Lignolitik Isolat Bakteri}

Seleksi Aktivitas Lignolitik Isolat Bakteri dilakukan untuk melihat kemampuan bakteri dalam mendegradasi lignin di dalam media. Hal ini dinyatakan dalam bentuk pengukuran indeks lignolitik. Hasil uji dapat dilihat pada Tabel 1. 
Tabel 1. Aktivitas lignolitik Isolat Bakteri Pendegradasi Pewarna No Kode Isolat Warna Zona Rasio Aktivitas

\begin{tabular}{cccc}
\hline 1 & NC1 & 3 & 19.75 \\
2 & NC6 & 3 & 17,5 \\
3 & NC3 & 3 & 17,25 \\
4 & C5 & 2 & 16,5 \\
5 & NC2 & 3 & 15 \\
6 & IN7 & 2 & 12 \\
7 & IN1 & 2 & 11,75 \\
8 & NC4 & 2 & 11,75 \\
9 & C1 & 2 & 11,5 \\
10 & NC5 & 3 & 11,29 \\
11 & IN3 & 2 & 9,75 \\
12 & IN2 & 2 & 7,75 \\
\hline
\end{tabular}

*Ket: $0=$ Tidak berwarna, $1=$ Putih (perubahan warna sedikit),

$2=$ Coklat muda, $3=$ Coklat tua, $4=$ coklat tua $(\geq 10)$.

Tabel 1 menunjukkan hasil seleksi semikuanitatif bakteri pendegradasi lignin dalam medium nutrient agar yang mengandung asam tanat. Seleksi berdasarkan besarnya rasio aktivitas lignolitik, yaitu perbandingan antara diameter zona coklat dengan diameter koloni bakteri. Makin besar rasio makin besar pula aktivitas lignolitik yang dimiliki isolat tersebut.

Rao (1982) membagi kelas jamur lignolitik berdasarkan warna coklat yang terbentuk dan selisih antara diameter zona coklat dengan diameter plug koloni jamur. Namun, belum ada penggolongan khusus untuk bakteri. Oleh karena itu untuk seleksi bakteri pendegradasi lignin digunakan parameter standar yang biasa digunakan dalam hal ini yaitu berdasarkan antara rasio antara diameter zona coklat dengan diameter koloni bakteri.

Perbedaan intensitas warna coklat dan waktu pembentukan zona coklat diperkirakan juga menggambarkan tinggi-rendahnya aktivitas mikroba dalam mendegradasi asam tanat, yang juga mencerminkan aktivitas degradasi lignin. Oleh karena itu, intensitas warna coklat dan rasio antara diameter zona dengan diameter koloni digunakan sebagai kriteria penentuan seleksi aktivitas lignolitik isolat bakteri (Martani et al., 2003).

Data pada tabel 1 Menunjukkan bahwa warna zona tidak selalu menggambarkan besarnya aktivitas lignolitik, misalnya isolat IN1 memiliki rasio 11,75 dengan warna zona coklat muda (2), dan C5 memiliki rasio 16,5 dengan warna zona coklat 
muda (2), sedangkan isolat NC5 memiliki rasio 11,29 dengan warna zona coklat tua (3) oleh karena itu dalam penelitian ini seleksi didasarkan atas rasio lignolitik sedangkan warna sebagai data pendukung. Untuk memperoleh isolat bakteri unggul yang mampu mendekolorisasi pewarna, maka dilakukan uji dekolorisasi pada pewarna Naftol AS-BO - Blue B, sebagai seleksi kuantitatif.

\section{Seleksi Kuantitatif Dalam Dekolorisasi Pewarna Naftol ASBO - Blue B \\ Dua belas isolat yang} memiliki aktivitas lignolitik terbaik
( $\geq 5$ ), dilakukan uji dekolorisasi. Uji dekolorisasi ditentukan berdasarkan isolat yang mampu mendekolorisasi pewarna naftol $A S$-BO-blue $B$.

Hasil yang diperoleh, diketahui bahwa duabelas isolat yang diujikan mampu mendekolorisasi pewarna naftol $A S$-BO-blue $B$. Tiga isolat mempunyai aktivitas dekolorisasi pewarna naftol $A S-B O$ - blue $B$ tertinggi. Hasil pengamatan secara visual dekolorisasi oleh 3 isolat bakteri dapat dilihat dalam Gambar 1 dan data pengamatan dekolorisasi periodik disajikan dalam Tabel 2
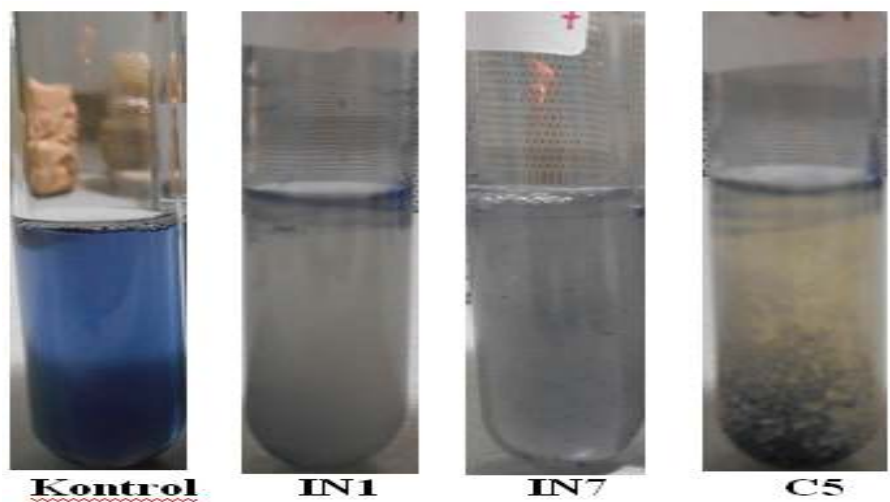

Gambar 1. Dekolorisasi Visual Pewarna Naftol ASBO-Blue B Setelah 24 jam Oleh Isolat Bakteri.

Tabel 2. Dekolorisasi Pewarna Naftol AS-BO-Blue B oleh Isolat Bakteri setelah 24 jam

\begin{tabular}{cccc}
\hline No & Isolat & Aktivitas Lignolitik & \% Dekolorisasi \\
\hline 1 & IN1 & 11,75 & 58,91 \\
2 & IN7 & 12 & 57,92 \\
3 & C5 & 16,5 & 54,72 \\
\hline
\end{tabular}

Tabel 2, munjukkan bahwa degradasi pewarna naftol $A S-B O$ - blue $B$ secara berturut-turut oleh isolat IN1 dengan persentase 
$58,51 \%$, IN7 dengan persentase $57,65 \%$, C5 dengan persentase $53,94 \%$. Kemampuan isolat bakteri dalam dekolorisasi pewarna naftol $A S$-BO-blue $B$, karena adanya enzim lignolitik. Beberapa penelitian menunjukkan bahwa dekolorisasi pewarna merupakan asimilasi senyawa tersebut menjadi sumber $\mathrm{C}$ dan energi bagi pertumbuhan mikroorganisme (Ponraj et al., 2011).

Dekolorisasi limbah pewarna sebenarnya dapat dilakukan secara alami pada limbah pewarna tersebut namun waktu yang dibutuhkan cukup lama, oleh karena itu pemanfaatan bakteri lignolitik yang telah diisolasi diharapkan mampu memberikan beberapa keuntungan diantaranya dapat mempercepat terurai senyawa kompleks pewarna pada pengolahan limbah, sehingga limbah yang dihasilkan tidak toksik terhadap lingkungan.

\section{Karakterisasi dan Identifikasi Isolat Bakteri}

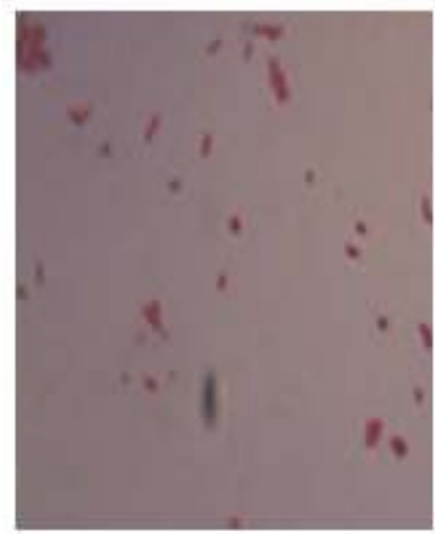

a

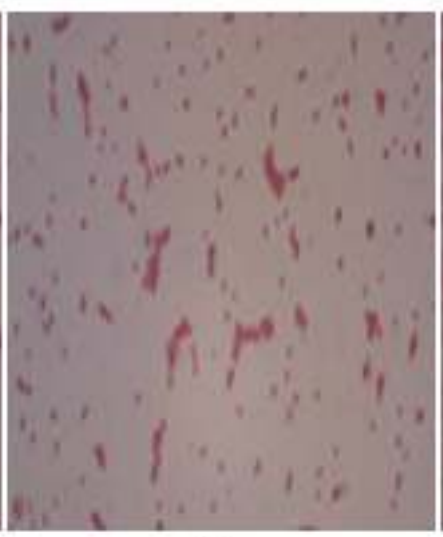

b

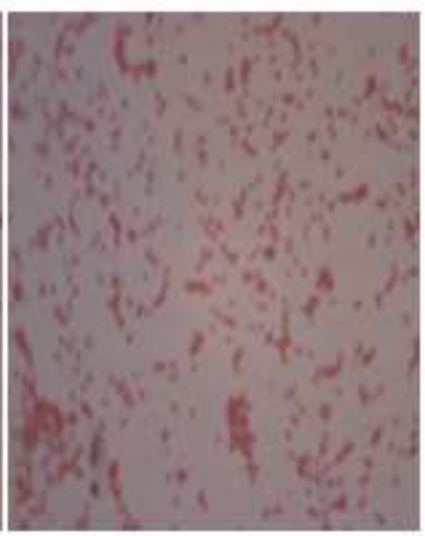

c

Gambar 2. Morfologi sel isolat bakteri (a) Isolat C5, (b) Isolat IN1,dan (c) Isolat IN7

Berdasarkan pengamatan terhadap sifat morfologis, fisiologis dan biokimia isolat C5 memiliki kedekatan dengan genus Enterobacter, sedangkan isolat IN1 dan IN7 memiliki kedekatan

\section{SIMPULAN}

Berdasarkan penelitian yang telah dilakukan, maka dapat disimpulkan bahwa dalam limbah dengan genus Brucella. Dalam penelitian ini ketiga isolat tersebut hanya dapat diidentifikasi sampai pada tingkat genus untuk memastikan spesies, maka perlu dilakukan analisis molecular.

pewarna tenun ikat terdapat bakteri lignolitik yang dapat berperan dalam dekolorisasi pewarna. Hasil isolasi yang telah dilakukan pada 
media NA modifikasi Asam tanat $3 \%$, diperoleh sebanyak 12 isolat lignolitik. Rasio lignolitik yang dihasilkan oleh duabelas isolat yaitu: 7,75-19,75.Berdasarkan uji dekolorisasi isolat IN1, IN7 dan C5 mampu mendegradasi pewarna Naftol ASBO-Blue B. Hasil identifikasi menunjukkan bahwa isolat C5 memiliki kedekatan dengan genus Enterobacter, sedangkan isolat IN1 dan IN7 memiliki kedekatan dengan genus Brucella.

\section{DAFTAR PUSTAKA}

Khehra MS, Saini HS, Sharma DK, Chadha BS and Chimni SS. 2005. Biodegradation of Azo Dye C.I. Acid Red 88 by an Anoxiceaerobic Sequential Bioreactor. Dyes and Pigments 70: 1-7.

Lavanya, C. 2014. Review Article Degradation of Toxic Dyes : A Review 3:189-199.

Martani E and Margino S. 1998.

Decolorization of Pulp Mill Effluents by White Rot Fungi and its Correlation to Lignin Degradation. Jurnal Biologi 2: 265-276.

Martani E, Rahayu SA, Murachman B and Hadi N. 2000. Optimization Condition of Bio-Proses for Phenol Degradation in Oil Refinery Waste Water. Jurnal Biologi. 2:127-133.

Martani E, Haedar N dan Margino S. 2003. Dekolorisasi Lindi Hitam dan Degradasi Lignin oleh Bakteri Micrococcus sp. SPH-9 serta Bacillus sp. SPH-10. Jurnal Biologi. 3:81-93.

Martani E, Margino S, dan Nurnawati E. 2011. Isolasi dan Karaterisasi Jamur Pendegradasi Zat Pewarna Tekstil. Jurnal Manusia dan Lingkungan. Vol 18. 2:127136.

Pandey A, Singh P and Iyengar L. 2007. Bacterial Decolorization and Degradation of Azo Dyes. International biodeterodation and biodegradation journal. 59: $73-84$

Sandhya, S. 2010. Biodegradation of Azo Dyes Under Anaerobic Condition: Role of Azoreductase. National Environmental Engineering Research Institute. 9:39-57.

Saratale RG, Saratale GD, Chang JS and Govindwar SP. 2011. Bacterial Decolorization and Degradation of Azo Dyes: A review. Journal of the Taiwan Institute of Chemical Engineers. 42:138-157.

Setiawan B dan Suwarningdyah RR. 2014. Strategi Pengembangan Tenun Ikat Kupang Provinsi Nusa Tenggara Timur. Jurnal Pendidikan dan Kebudayaan Vol 20 (3).

Siswanto, Suharyanto, dan Fitria R. 2007. Produksi dan Karakteristik Lakase Omphilina sp. Menara Perkebunan. 75:107-110. 